\title{
Design and Synthesis of Triazole-Phthalimide Hybrids with Anti- inflammatory Activity
}

\author{
Shalom P. de O. Assis,${ }^{a, b, c}$ Moara T. da Silva, ${ }^{a}$ Filipe Torres da Silva, ${ }^{a, c}$ Mirella P. Sant'Anna, ${ }^{c}$ \\ Carolina M. B. de Albuquerque Tenório, ${ }^{c}$ Caroline F. Brito dos Santos, ${ }^{c}$ \\ Caíque S. M. da Fonseca, ${ }^{b}$ Gustavo Seabra, ${ }^{d}$ Vera L. M. Lima, ${ }^{* b}$ and Ronaldo N. de Oliveira*,a \\ ${ }^{a}$ Laboratório de Síntese de Compostos Bioativos, Departamento de Química, Universidade Federal Rural de \\ Pernambuco; Rua Dom Manoel de Medeiros s/n, Dois Irmãos, CEP 52171-900, Recife-PE, Brazil: ${ }^{b}$ Departamento \\ de Bioquímica, Universidade Federal de Pernambuco; Av. Prof. Moraes Rego, s/n, CEP 50.670-420. Recife-PE, \\ Brazil: ${ }^{c}$ Departamento de Medicina, Universidade Católica de Pernambuco; Av. do Príncipe, 526, CEP 50.050-900, \\ Recife-PE, Brazil: and ${ }^{d}$ Departamento de Química Fundamental; Av. Jornalista Anibal Fernandes, $s / n^{\circ}$ Cidade \\ Universitária, CEP 50.740-560, Recife-PE, Brazil.
}

Received August 8, 2018; accepted November 6, 2018

Phthalimido-alkyl-1H-1,2,3-triazole derivatives 3a-d and 4a-d were efficiently synthesized using 1,3-dipolar cycloaddition reaction. Anti-inflammatory activity and toxicity studies were performed. The results demonstrated that all the tested compounds reduced carrageenan-induced paw edema and indicated no lethality for toxicity against Artemia salina and acute toxicity in vivo $\left(\mathrm{LD}_{50}\right.$ up to $\left.1 \mathrm{~g} \mathrm{~kg}^{-1}\right)$. Furthermore, the structure of phthalimide linked to phenyl group proved to be more active than the compounds containing benzothiazole moiety. Structural modifications such as removal of the phthalimide group and subsequent acetylation, to exemplify a non-cyclic amide, demonstrate that the phthalimide and triazole moieties are important for design of potent candidates with anti-inflammatory drug proprieties. Docking into the cyclooxygenase-2 (COX-2) confirms the importance of the phthalimide and triazole groups in the anti-inflammatory activity. The histopathological studies showed that the compounds 3a-d and $4 a-d$ did not cause serious pathological lesions liver or kidneys.

Key words phthalimide; triazole; anti-inflammatory activity; toxicity

Phthalimido-alkyl-1H-1,2,3-triazole derivatives were efficiently synthesized. All synthesized compounds reduced carrageenan-induced paw edema and indicated no lethality for toxicity. Phthalimide linked to phenyl group demonstrated to be more active than those containing benzothiazole moiety. The histopathological studies showed that the compounds did not cause serious pathological lesions liver or kidneys.

Phthalimides are considered an important synthon for organic synthesis and several of their derivatives, after biological evaluation, have been reported to have interesting pharmacological proprieties. ${ }^{1)}$ A molecular diversity has emerged from the phthalimide scaffold linked to other heterocyclic nucleus; for example, benzothiazoles have shown significant cytotoxic activity against human cancer cells lines, such as Burkitt's lymphoma CA46, chronic myelogenous leukaemia K562 and human hepatoma SKHep1. ${ }^{2)}$

The search for molecular hybrids from bioactive chemical entities to enhance their original biological activities has been a goal of the scientific community. Triazole is an attractive heterocycle which has the potential of having a wide range of applications in the field of medicinal chemistry. ${ }^{3-6)}$

1,2,3-Triazole has particular proprieties such as metabolic stability and slow degradation. This specific triazolic structure can also be an acceptor and/or donor to hydrogen bond formation. ${ }^{7)}$ For instance, our research reported an intramolecular $\mathrm{CH}-\mathrm{O}$ hydrogen bond between $\mathrm{H}_{5}$-triazolic and the endocyclic oxygen of $N$-glucopyranoside. ${ }^{8)}$ In addition, an assisted version of a classical E2 elimination mechanism to furnish conjugated alkene after triazole protonation was described by de Oliveira et al. $^{9}$ )
Since the discovery of click chemistry by Fokin and Sharpless, ${ }^{10)}$ and Tornøe and Meldal, ${ }^{11)}$ reactions involving copper-catalyzed azide-alkyne cycloaddition (CuAAC) have gained popularity as a general strategy for the synthesis of 1,4-disubstituted 1,2,3-triazoles. Recently, several of these compounds have been prepared employing the click chemistry protocol ${ }^{12,13)}$ providing rapid access to small molecules as privileged medicinal scaffolds. ${ }^{14,15)}$ 1,2,3-Triazole has shown a broad range of biological activities, such as anti-nociceptive, ${ }^{16)}$ enzyme inhibitive ${ }^{17,18)}$ and, as recently reported by us, antitumoral $^{19)}$ and anti-inflammatory. ${ }^{20,21)}$

In 2012, Shafi et al. ${ }^{16)}$ analyzed the efficacy of 1,2,3-triazole compounds based on studies of structure-activity relationships. They focused on the three structural components: i) the nature of the group attached to triazolic ring; ii) the substituent (functional groups); iii) the position of the substitutions on the aromatic ring. They synthesized bis-heterocycle containing 2-mercapto-benzothiazole and triazole, which demonstrated potential anti-inflammatory activity.

Pharmacophoric moieties of phthalimide analogues were studied by Lima et $a l^{22)}$ The authors concluded that phthalimide ring plays an important role in the anti-inflammatory activity. These analogues were evaluated and revealed ability to inhibit tumor necrosis factor (TNF- $\alpha$ ) levels in the bronchoalveolar lavage fluid of mice lungs treated with them.

Phthalimide and 1,2,3-triazole nucleus have been applied as a strategy to design new molecular hybrids. In previous studies, we reported on the synthesis ${ }^{23,24)}$ and biological activities $^{19,21,25,26)}$ of these structures to valorize them as promising "drug-like" molecules. One example of phthalimide- 


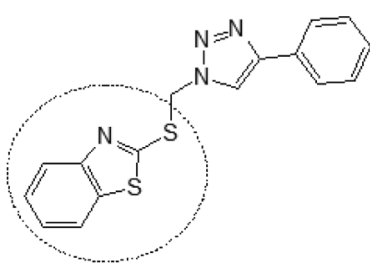

Mercaptobenzothiazole-triazole

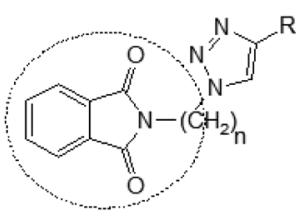

Phthalimide-triazole
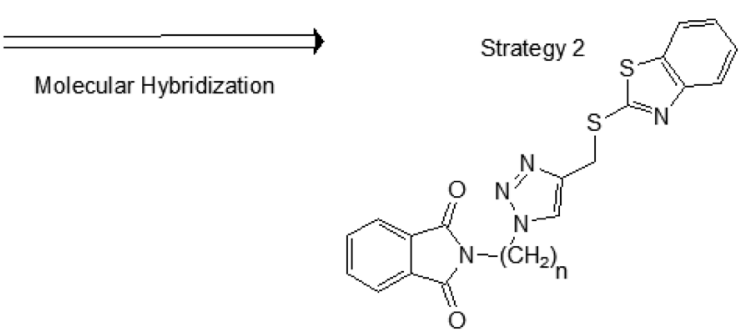

Mercaptobenzothiazole-triazole phthalimide

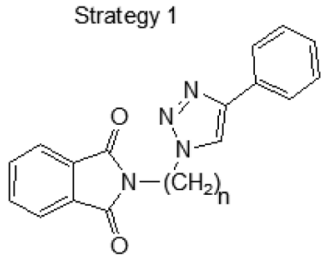

Phenyl-triazole phthalimide
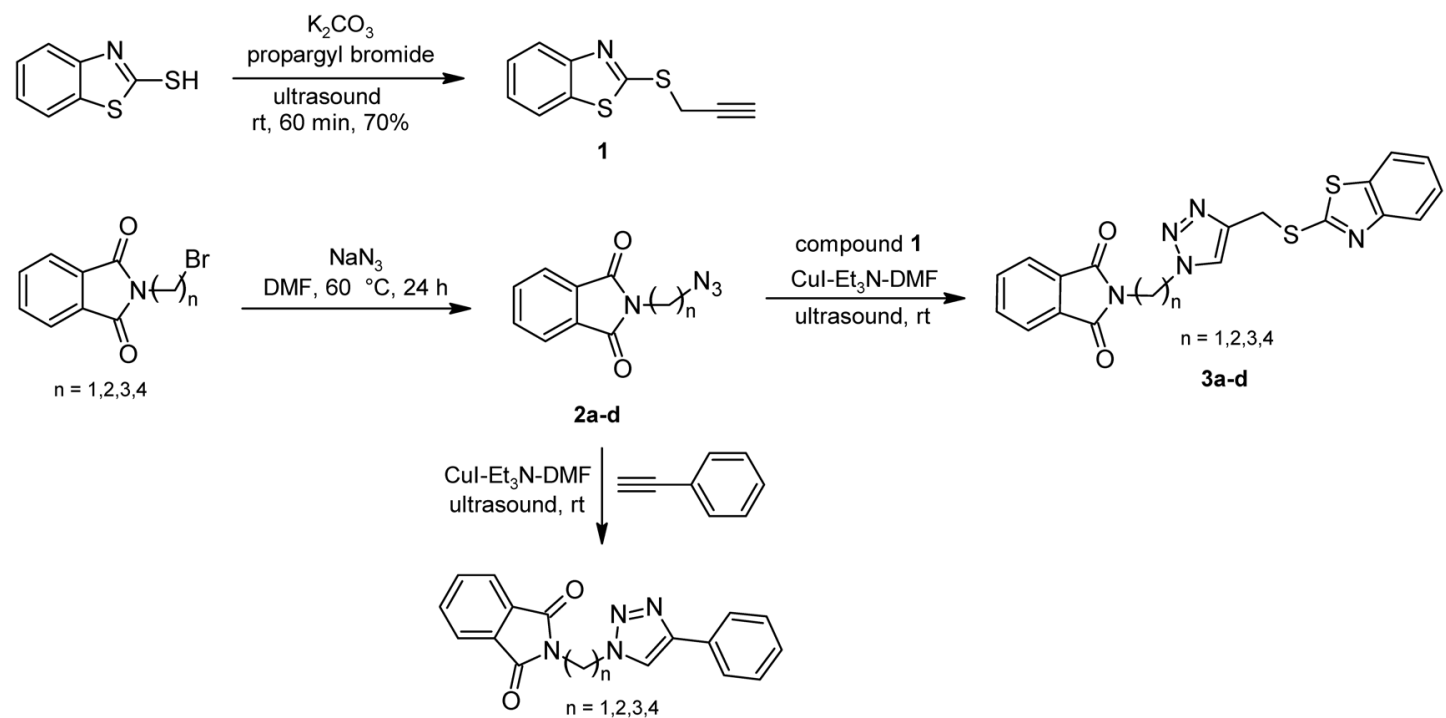

$4 a-d$

Chart 1. Synthesis of 1,2,3-Triazole Compounds $\mathbf{3 a - d}$ and $\mathbf{4 a - d}$

triazole molecule was synthesized and studied for its antiinflammatory activities. ${ }^{20}$

The present work concerns the synthesis of phthalimidelinked to 1,2,3-triazole using a protocol based on click chemistry. The toxicity and anti-inflammatory activities were tested on mice, and docking studies show the mode of action of the compounds. Based on the heterocycles, namely phthalimide, triazole and benzothiazole, this research proposed two strategies for molecular hybridization towards new anti-inflammatory compound leads ( $c f$. Fig. 1).

\section{Results and Discussion}

Chemistry We started with the synthesis of $\mathbf{1}$ and $\mathbf{2 a - d}$. The propargyl bromide and 1,3-benzothiazole-2-thiol reacted to afford $\mathbf{1}$ with yield of $70 \%$. The azide-phthalimides $(\mathbf{2 a}-\mathbf{d})$ were synthesized, according to the literature description, in $60-93 \%$ yields. $^{24)}$
Recently, our research group developed an efficient click protocol for the preparation of $N$-phthalimidoalkyl $1 H-1,2,3-$ triazoles using $N, N$-dimethylformamide (DMF) as the solvent, copper iodide $(\mathrm{CuI})$ and triethylamine $\left(\mathrm{Et}_{3} \mathrm{~N}\right)$ under ultrasound irradiation for $30 \mathrm{~min}$ at room temperature. ${ }^{24)}$ Under these conditions, eight compounds $\mathbf{3 a}-\mathbf{d}$ and $\mathbf{4 a}-\mathbf{d}$ were synthesized in good to excellent yields of 70-96\% (Chart 1 and Table 1).

The structures of the compounds $\mathbf{3 a}-\mathbf{d}$ and $\mathbf{4 a}-\mathbf{d}$ were characterized by IR, ${ }^{1} \mathrm{H}$ - and ${ }^{13} \mathrm{C}-\mathrm{NMR}$ spectra and elemental analysis. The ${ }^{1} \mathrm{H}-\mathrm{NMR}$ data for alkyl groups were well characterized, showing the presence of methylene groups with multiplicity according to the structural sizes chain. The phthalimide protons appeared between $\delta 7.64$ and $7.91 \mathrm{ppm}$ as second-order multiplets. The presence of the $\mathrm{H}_{5}$-triazolic in the aromatic region was identified as a singlet in the downfield region as a shielded proton $(\delta 7.64-8.64 \mathrm{ppm})$ confirming the 1,3-dipolar cycloaddition reaction. 
Table 1. Chemical Structures, Melting Points, Yields and $\log P$ of the Compounds 3a-d and 4a-d

\begin{tabular}{|c|c|c|c|c|}
\hline Compounds & Chemical structures & $\begin{array}{c}\text { M.p. }{ }^{\circ} \mathrm{C} \\
\text { (Lit.) }\end{array}$ & $\begin{array}{l}\text { Yield, \% } \\
\text { (Lit. data) }\end{array}$ & $\log P^{*}$ \\
\hline $3 \mathbf{a}$ & & $136-139$ & 91 & $3.75 \pm 0.60$ \\
\hline $3 \mathbf{b}$ & & $140-142$ & 85 & $3.92 \pm 0.58$ \\
\hline $3 c$ & & $\begin{array}{c}124-127 \\
(103-105)^{27)}\end{array}$ & $81(78)$ & $4.13 \pm 0.57$ \\
\hline 3d & & $\begin{array}{c}109-113 \\
(92-94)^{27)}\end{array}$ & $85(84)$ & $4.67 \pm 0.57$ \\
\hline $4 a$ & & $\begin{array}{c}200-203 \\
(186-188)^{28)}\end{array}$ & $96(37)$ & $2.85 \pm 0.61$ \\
\hline $4 b$ & & $\begin{array}{c}187-189 \\
(157-158)^{29)}\end{array}$ & $93(97)$ & $3.02 \pm 0.59$ \\
\hline $4 c$ & & $144-146$ & 70 & $3.23 \pm 0.58$ \\
\hline $4 d$ & & $115-118$ & 80 & $3.76 \pm 0.58$ \\
\hline
\end{tabular}

\section{Pharmacology}

\section{Toxicity against Artemia salina}

Artemia salina has been used as an indicator of toxicity for evaluating chemicals, pesticides and polluting products among other substances. A. salina has been reported as a good way to determine and evaluate the biological activity (toxicity) of a particular chemical compound, or a natural product by using the median lethal concentration $\left(\mathrm{LC}_{50}\right)$. None of the eight compounds synthesized in this study showed lethality against Artemia salina for concentrations up to $1000 \mathrm{ppm}$.

Acute Toxicity in Vivo

The acute toxicity study using the eight new phthalimide triazoles-linked benzoheterocycles indicated that the dose $\left(250 \mathrm{mg} \mathrm{kg}^{-1}\right)$ required for anti-inflammatory activity was in the safe therapeutic range, with a single dose administered orally to mice having an $\mathrm{LD}_{50}>1 \mathrm{~g} \mathrm{~kg}^{-1}$. Thus, this dose limit of the compounds did not result in any lethality or observable behavioral changes such as writhing, gasping, palpitation, and decreased respiratory rate, in the treated mice.

In Vivo Anti-inflammatory Activity The anti-inflammatory assays were preceded by the acute toxicity tests in mice. Anti-inflammatory tests were performed for compounds $\mathbf{3 a}-\mathbf{d}$ and $4 \mathbf{a}-\mathbf{d}$ in the groups of mice treated with a dose of $250 \mathrm{mg}$ $\mathrm{kg}^{-1}$. All the compounds exhibited anti-inflammatory properties when compared with acetylsalicylic acid (ASA) and ibuprofen in the same dosage (Table 2, Figs. 2 and 3).

The benzoheterocycle-triazole-phthalimides (BTP) 3a-d showed less anti-inflammatory activity than that observed for ASA and ibuprofen. These compounds $\mathbf{3 a}-\mathbf{d}$ were the least active of all of the tested drugs. These compounds decreased the inflammation in paw edema carrageenan-induced by 14.2 , $18.0,30.1,20.1 \%$, respectively, at $4 \mathrm{~h}$ post-carrageenan; for inhibition at $24 \mathrm{~h}$ the results were $16.8,11.0,19.4$ and $15.8 \%$ of inhibitions, respectively (cf. Fig. 3-A).

On the other hand, when 2-mercapto benzothiazole was replaced by phenyl, the results were improved for the com- 
Table 2. Anti-inflammatory Activity of Phthalimide Triazoles-Linked Benzoheterocycles Compounds 3a-d and 4a-d in Carrageenan-Induced Edema in Mice

\begin{tabular}{|c|c|c|c|c|c|c|c|c|c|}
\hline \multirow{3}{*}{ Compound } & \multicolumn{6}{|c|}{ Paw size (mm) } & \multicolumn{3}{|c|}{$\begin{array}{c}\text { Anti-inflammatory activity } \\
(\% \text { inhibition })\end{array}$} \\
\hline & \multicolumn{6}{|c|}{ Time (h) } & \multicolumn{3}{|c|}{ Time $(\mathrm{h})$} \\
\hline & 1 & 2 & 3 & 4 & 24 & 48 & 2 & 4 & 24 \\
\hline $3 \mathbf{a}$ & $4.356 \pm 0.395$ & $4.146 \pm 0.273$ & $3.984 \pm 0.159$ & $3.558 \pm 0.307^{* *}$ & $3.450 \pm 0.400 * * *$ & $3.496 \pm 0.360 * *$ & 4.8 & 14.2 & 16.8 \\
\hline $3 \mathbf{b}$ & $3.876 \pm 0.581$ & $3.550 \pm 0.421$ & $3.422 \pm 0.340$ & $3.180 \pm 0.167$ & $3.450 \pm 0.400$ & $3.492 \pm 0.363$ & 8.4 & 18.0 & 11.0 \\
\hline $3 c$ & $4.186 \pm 0.285$ & $3.572 \pm 0.259^{*}$ & $3.204 \pm 0.413^{* * *}$ & $2.928 \pm 0.400^{* * *}$ & $3.372 \pm 0.277^{* *}$ & $3.472 \pm 0.271 * *$ & 14.7 & 30.1 & 19.4 \\
\hline 3d & $3.866 \pm 0.217$ & $3.678 \pm 0.258$ & $3.524 \pm 0.240$ & $3.088 \pm 0.522 * *$ & $3.256 \pm 0.186^{*}$ & $3.326 \pm 0.203^{*}$ & 5.1 & 20.1 & 15.8 \\
\hline $4 a$ & $4.285 \pm 0.194$ & $4.065 \pm 0.104$ & $3.755 \pm 0.089^{* * *}$ & $2.820 \pm 0.107^{* * *}$ & $2.760 \pm 0.184 * * *$ & $3.283 \pm 0.164^{* * *}$ & 5.1 & 34.2 & 35.6 \\
\hline $4 b$ & $4.263 \pm 0.176$ & $3.885 \pm 0.225$ & $3.158 \pm 0.099 * * *$ & $2.463 \pm 0.457 * * *$ & $3.408 \pm 0.053 * * *$ & $3.568 \pm 0.092 * *$ & 8.8 & 42.5 & 20.0 \\
\hline $4 c$ & $4.395 \pm 0.351$ & $3.380 \pm 0.422 * * *$ & $3.243 \pm 0.309^{* * *}$ & $2.595 \pm 0.291 * * *$ & $3.798 \pm 0.098 *$ & $3.938 \pm 0.061$ & 23.1 & 40.9 & 13.6 \\
\hline $4 d$ & $4.505 \pm 0.267$ & $4.188 \pm 0.179$ & $3.223 \pm 0.094 * * *$ & $2.303 \pm 0.332 * * *$ & $3.498 \pm 0.188^{* * *}$ & $3.745 \pm 0.110^{* * *}$ & 7.0 & $\begin{array}{c}48.9 \\
(117.8)^{a)}\end{array}$ & 22.4 \\
\hline ASA & $4.584 \pm 0.121$ & $4.360 \pm 0.217^{* * *}$ & $4.372 \pm 0.190^{* * *}$ & $2.670 \pm 0.402^{* * *}$ & $2.590 \pm 0.359 * * *$ & $2.574 \pm 0.296^{* * *}$ & 5.2 & 41.5 & 43.5 \\
\hline Ibuprofen & $4.644 \pm 0.200$ & $4.272 \pm 0.190^{* * *}$ & $3.234 \pm 0.095 * * *$ & $2.596 \pm 0.268^{* * *}$ & $2.756 \pm 0.323 * * *$ & $2.634 \pm 0.286^{* * *}$ & 8.3 & 45.2 & 41.4 \\
\hline $1 \% \mathrm{CMC}$ & $4.674 \pm 0.199$ & $4.915 \pm 0.096$ & $5.442 \pm 0.359^{* * *}$ & $5.567 \pm 0.336^{* * *}$ & $5.592 \pm 0.335^{* * *}$ & $4.434 \pm 0.191$ & -3.8 & -17.6 & -18.1 \\
\hline
\end{tabular}

Data were expressed as mean \pm standard deviation. $* p<0.05 ; * *<<0.01 ; * * p<0.001 v s$. left hind paw. One-way ANOVA followed by Bonferroni posttest. $a$ ) Potency: was expressed of the tested compound relative to ASA at $4 \mathrm{~h}$ as best result $(\mathbf{4 d}: 48.9 / 41.5=117.8)$.

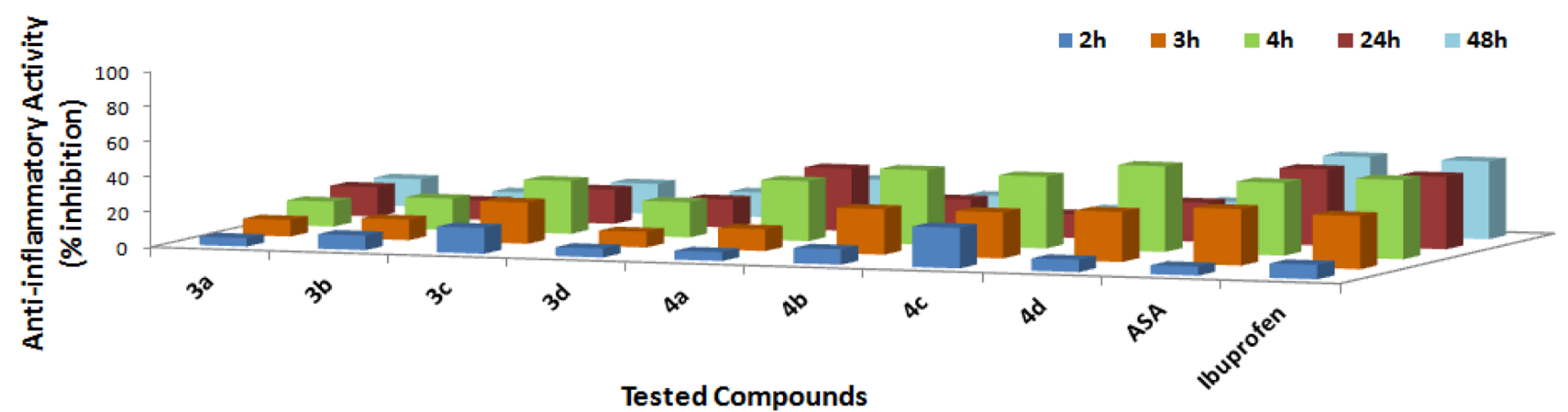

Fig. 2. In Vivo Anti-inflammatory Activity of Phthalimide-Linked to Triazoles Compounds (3a-d), (4a-d), Ibuprofen and ASA on CarrageenanInduced Edema in Mice

(Color figure can be accessed in the online version.)

pounds $\mathbf{4 a - d}$. In general, the activity was enhanced according to the size of the aliphatic chain ( $c f$. Fig. 3-B). The inhibition of inflammation induced by compound $\mathbf{4 a}$ proved to be timedependent as even after $24 \mathrm{~h}$ compound $\mathbf{4 a}$ presented inflammatory inhibition by $35 \%$ (Table 2 ). In contrast, all the other phenyl derivatives $\mathbf{4 b}-\mathbf{d}$ had a decrease in the inflammation process by the end of $24 \mathrm{~h}$.

The anti-inflammatory profile of compound $\mathbf{4 d}$ (48.9\% inhibition at $4 \mathrm{~h}$ and $22.4 \%$ inhibition at $24 \mathrm{~h}$ post-carrageenan) was better than standard ASA and ibuprofen when comparing at $4 \mathrm{~h}$, i.e., ASA $41.5 \%$ and ibuprofen $45.2 \%$ of inhibition. Concerning compound $\mathbf{4 d}$, the best result, that 2-mercaptobenzothiazole was replaced by phthalimide core using our molecular hybridization strategy (see Fig. 1), the results indicate that anti-inflammatory activity was improved from $46.6 \% / 3 \mathrm{~h}^{16)}$ to $48.9 \% / 4 \mathrm{~h}$ (this work), more active even after $4 \mathrm{~h}$.

The compounds $\mathbf{4 b}$ and $\mathbf{4} \mathbf{c}$ presented satisfactory antiinflammatory activities with values of 42.5 and $40.9 \%$, respectively; these results were highest for the $4 \mathrm{~h}$ and comparable with ASA and ibuprofen.

In general, the structural correlation of the synthesized compounds $\mathbf{3 a}-\mathbf{d}$ and $\mathbf{4 a}-\mathbf{d}$ considering their aliphatic chain size, relative to individual series, reveals difference in the anti-inflammatory activity. The compounds $\mathbf{3 a - d}$ show $\log$ $p=3.75-4.67$ values, and $\%$ of inhibition from 14 to $30 \%$. On the other hand, compounds $4 \mathbf{a}-\mathbf{d}$ show values of $\log$ $p=2.85-3.76$, and $\%$ of inhibition between 34 and $48.9 \%$ (Tables 1,2$)$. These results indicate that the tendency to penetrate lipid barriers seems no very important data to be considered for pharmacokinetic properties and drug design.

In order to investigate the influence of phthalimide scaffold in the inflammatory process, compound $\mathbf{4 d}$ was hydrolyzed by treatment with a mixture of methanol/hydrazine to furnish amino-triazole 5 in $87 \%$ yield (Chart 2). Afterwards, acetylation of amino-triazole 5 lead to triazole-acetamide $\mathbf{6}$ in yield of $61 \%$; thus the structural effect from cyclic imide was also investigated. On the NMR spectra of $N$-acetylamino-triazole 6 was observed doubling signals due to presence of $N$-acetyl rotamers (see Experimental data).

The experiment revealed, after $4 \mathrm{~h}$, non-significant variation in anti-inflammatory activity of the compound $\mathbf{5}$ compared with 4d (Table 3). These results also indicate the importance of the amino-triazole moiety in the anti-inflammatory process. Triazole-acetamide $\mathbf{6}$ was less active (31\%) than $\mathbf{4 d}$ or $\mathbf{5}$.

Histopathological Study Liver and kidneys of the mice were evaluated externally and did not show macroscopic dif- 
ferences between the control group (1\% carboxymethylcellulose (CMC)) and the groups treated with compounds $\mathbf{3 a}-\mathbf{d}$ and $\mathbf{4 a}-\mathbf{d}$. The livers, sliced with a scalpel, did not show any internal macroscopically significant differences.

The control and mice kidneys tested for compounds $\mathbf{3 a}-\mathbf{d}$ and $\mathbf{4 a -} \mathbf{d}$ showed a mild, sometimes cortical, chronic inflammatory infiltrate underlying the pelvic, focal and non-specific epithelial lining in the samples (Fig. 4).

In liver microscopy, all the organs studied showed vascular congestion and non-specific chronic inflammatory infiltrates, focal and portal. The livers in the control group and the animals tested for compounds $\mathbf{3} \mathbf{a}, \mathbf{3} \mathbf{b}$, and $\mathbf{4 a}-\mathbf{d}$ exhibited minimal foci of hepatocyte necrosis. Some associated polymorphonuclear leukocytes could also be observed, with no signs of specificity (Fig. 5).

In the present study, there were minimal foci of hepatocyte necrosis in the mice that were tested for $\mathbf{3 a}-\mathbf{d}$ and $\mathbf{4 a}-\mathbf{d}$. The same finding was seen in the mouse that received $1 \% \mathrm{CMC}$. Due to the small amount of this alteration found in the evaluated organs, and because it was also present in the control animal, hepatocyte necrosis seems to be a nonspecific finding

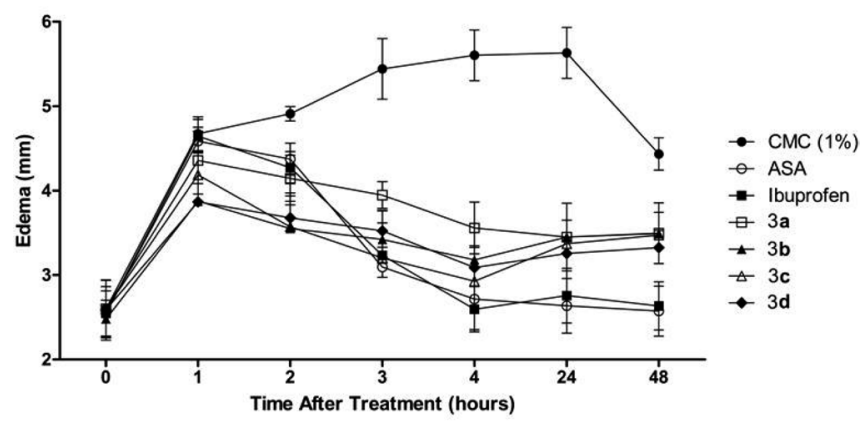

(3-A)

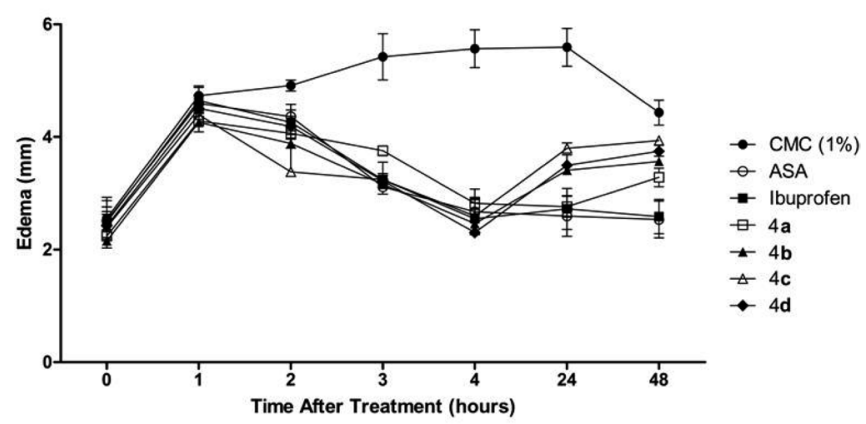

(3-B)

Fig. 3. Effect of the Triazole Derivatives on the Development of Edema Induced by $1 \%$ Carrageenan in Mice

(A) Compounds 3a-d; (B) Compounds $4 \mathbf{a}-\mathbf{d}$. with little clinical significance. The foci of necrosis and eventual hepatic steatosis, in addition to the single renal impairment with chronic granulomatous inflammatory process, in all that has been demonstrated, are not directly related to the use of $\mathbf{3 a}-\mathbf{d}$ and $\mathbf{4 a}-\mathbf{d}$ substances.

Molecular Docking The anti-inflammatory effects are associated to inhibition of cyclooxygenase- 2 (COX-2). The binding of the compounds to COX-2 is illustrated in Fig. 6, which shows molecule $\mathbf{4 d}$ in the active pocket of COX-2. Most inhibitors of COX-2 are carboxylic acids and bind in this same site by establishing H-bonds to Ser530 and Tyr385 through the carboxylate. In all phthalimides, the phthalimide moiety establishes a H-Bond to $\operatorname{Ser} 530$ (2.3 $\AA$ ). In 4a, the triazole makes a second weaker bond to Tyr385. With larger linker sizes this interaction is lost, and in $\mathbf{4 d}$ the triazole H-bonds to Tyr355 (1.9 $\AA$ ). In all cases, the phenyl makes only hydrophobic interactions with the surrounding residues. The FlexX score (binding energy) obtained for the best pose in $\mathbf{4 d}$ was $-16.00 \mathrm{~kJ} \mathrm{~mol}^{-1}$, which is comparable to the score for ASA $\left(-16.94 \mathrm{~kJ} \mathrm{~mol}^{-1}\right)$ and significantly stronger than Ibuprofen $\left(-11.68 \mathrm{~kJ} \mathrm{~mol}^{-1}\right)$. Substitution of the phenyl ring by mercaptobenzothiazole does not improve the interactions, as the size of the new substituent increases the steric clashes to the surrounding residues, resulting in a $-12.26 \mathrm{~kJ} \mathrm{~mol}^{-1}$ FlexX score for $\mathbf{3 d}$, which makes the same H-bonds as $\mathbf{4 d}$. Removing the phthalimide group, however, results in loss of the important interactions. Compounds $\mathbf{5}$ and $\mathbf{6}$ do not seem enter the binding site adequately and the FlexX score for the best pose of compound $\mathbf{5}$, for example, is only $-12.73 \mathrm{~kJ} \mathrm{~mol}^{-1}$ (Fig. 6). Compound $\mathbf{5}$ is making weak H-bonds to Glu524 and Phe470 but is far away from the catalytic residues Tyr385 and Ser530. Those are only weak bonds such that in other poses they are substituted by Asp347 and Glu346. In some poses, the triazole can make H-bonds to Gln350 or Ser530. In agreement with recent studies on different compounds, ${ }^{30,31)}$ our results demonstrate the important role of the phthalimide group in the biological effect, and indicate possible routes for future improvement.

\section{Conclusion}

The phthalimide 1,2,3-triazole compounds $\mathbf{3 a}-\mathbf{d}$ and $\mathbf{4 a -} \mathbf{d}$ were synthesized in good to excellent yields (70-96\%). All the compounds decreased the carrageenan-induced edema in mice, when compared with ASA and ibuprofen commercial

Table 3. Anti-inflammatory Activity (\% Inhibition) of 4d, 5 and 6

\begin{tabular}{crll}
\hline \hline Compound & $2 \mathrm{~h}$ & $4 \mathrm{~h}(\text { Potency })^{a)}$ & $24 \mathrm{~h}$ \\
\hline $\mathbf{4 d}$ & 7.0 & $48.9(108.0)$ & 22.4 \\
$\mathbf{5}$ & 16.0 & $47.9(106.0)$ & 26.5 \\
$\mathbf{6}$ & 3.8 & $31.0(68.6)$ & $37.0(81.9)^{a)}$ \\
\hline
\end{tabular}

a) Potency: was expressed of the tested compound relative to Ibuprofen at $4 \mathrm{~h}$.

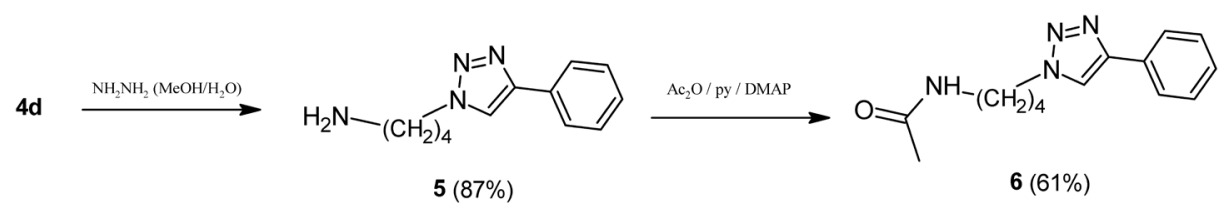

Chart 2. Synthesis of Derivatives 5 and $\mathbf{6}$ 

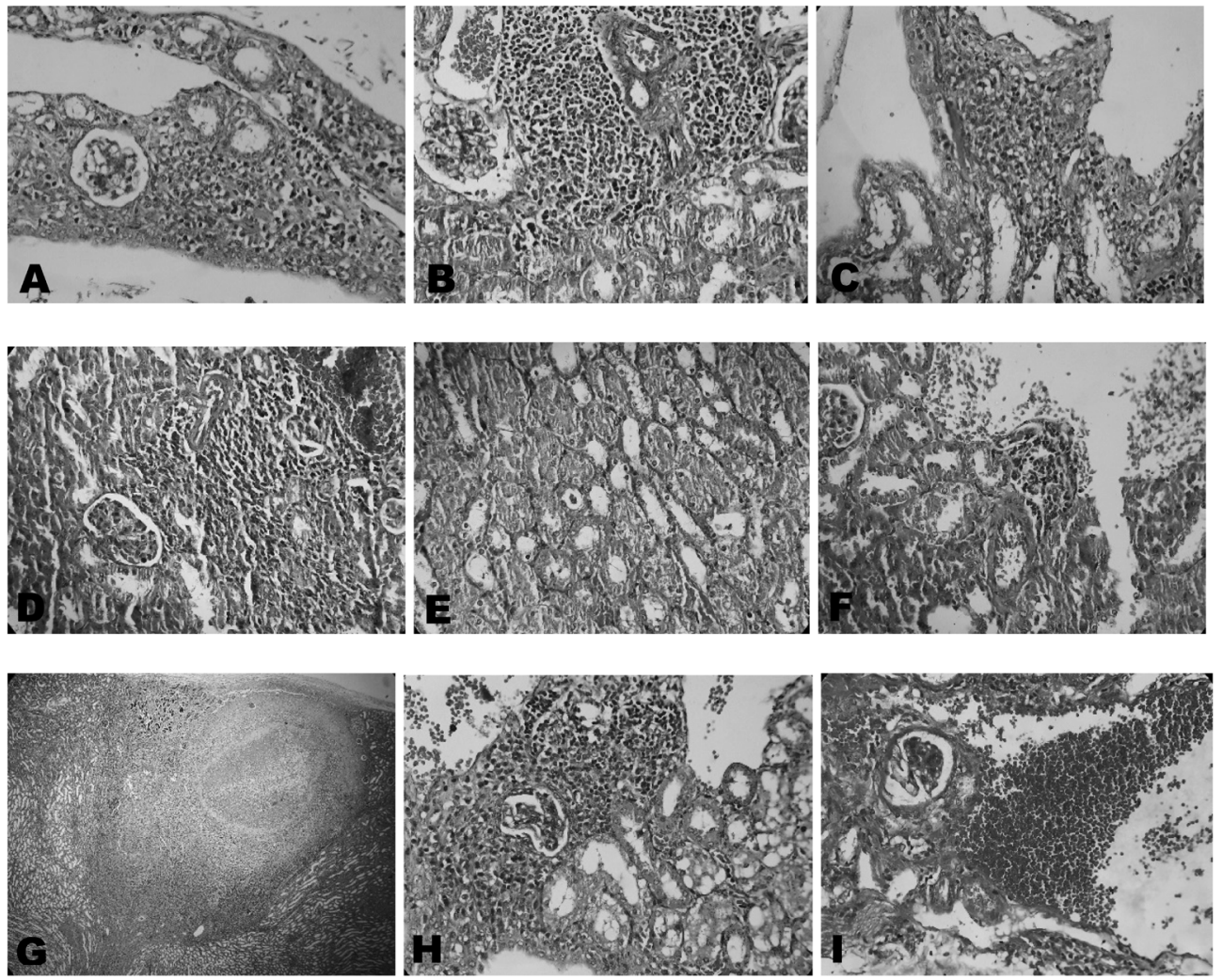

Fig. 4. Renal Histopathological Findings in the Mice Tested for Substances 3a-d, 4a-d and Control Negative: 3a (A), 3b (B), 3c (C), 3d (D), 4b (F), 4d $(\mathrm{H})$ and Control Negative $-1 \%$ CMC (I)

Renal tissue without inflammatory changes in the animal tested for $\mathbf{4 a}(\mathrm{E})$. Area of sclerosis and necrosis in the cortical-medullary transition in mouse kidney tested for compound $4 \mathbf{c}(\mathrm{G})$. (H\&E $\times 40$ to $\times 400)$.

drugs. The best activities were for the compounds containing the phenyl group. The results demonstrated that the compounds $\mathbf{4 a}$ and $\mathbf{4 d}$ have adequate anti-inflammatory activities at $24 \mathrm{~h}(35.6 \%)$ and $4 \mathrm{~h}(48.9 \%)$ post-carrageenan, respectively. Docking into the COX-2 confirms the importance of the phthalimide and triazole groups in the anti-inflammatory activity. The histopathological studies showed that the compounds $\mathbf{3 a}-\mathbf{d}$ and $\mathbf{4 a}-\mathbf{d}$ did not cause serious pathological lesions liver or kidneys. These new compounds may represent a novel class of potent anti-inflammatory agents.

\section{Experimental}

Chemistry Melting points were determined in an open capillary tube and performed on a PFM II BioSan apparatus. Elemental analyses were carried out in an EA1110 CHNS-O analyzer. The infrared spectra were recorded on an IFS66 Bruker spectrophotometer using $\mathrm{KBr}$ discs. ${ }^{1} \mathrm{H}$ - and ${ }^{13} \mathrm{C}-\mathrm{NMR}$ were obtained with a Varian Unity Plus-300 and $400 \mathrm{MHz}$ spectrometer using $\mathrm{CDCl}_{3}$ or DMSO- $d_{6}$ as the solvent. Purification was performed by column chromatography on Merck silica gel 60 (70-230 mesh), using a system hexane-EtOAc $(1: 1)$, and the purity of fractions were monitored by TLC analysis on a $\mathrm{GF}_{254}$ plate.

Synthesis of Terminal Alkyne (1) The acetylene 1 was prepared according to the procedure described in the literature, as well as the ${ }^{1} \mathrm{H}$ - and ${ }^{13} \mathrm{C}$-NMR data were in agreement with the literature. ${ }^{8)}$

Synthesis of $\boldsymbol{N}$-(Azidoalkyl)phthalimide (2a-d) The azide compounds $\mathbf{2} \mathbf{a}-\mathbf{d}$ were prepared according to the proce- dure described in the literature. ${ }^{27)}$ The ${ }^{1} \mathrm{H}$ - and ${ }^{13} \mathrm{C}-\mathrm{NMR}$ are in accordance with previously reported data. ${ }^{27)}$

Synthesis of 1,4-Disubstituted 1,2,3-Triazoles (3a-d) and (4a-d) The 1,2,3-triazoles $\mathbf{3 a}-\mathbf{d}$ and $\mathbf{4 a}-\mathbf{d}$ were prepared according to the procedure described in the literature. ${ }^{24)}$

4-(Benzothiazol-2-ylsulfanyl)-methyl-1-( $N$-phthalimidomethyl)-1 $H$-1,2,3-triazole (3a)

Brown solid; mp: $136-139^{\circ} \mathrm{C}$; Rf 0.4 (Hexane-EtOAc, $4: 6)$; IR (KBr) $v_{\max } 3127,1780,1716,1467,1428,1348$, 997, $712 \mathrm{~cm}^{-1}$; ${ }^{1} \mathrm{H}-\mathrm{NMR}\left(400 \mathrm{MHz}, \mathrm{CDCl}_{3}\right): \delta=8.07$ (s, $1 \mathrm{H}$, $\left.\mathrm{H}_{\text {triaz }}\right), 8.01\left(\mathrm{~d}, 1 \mathrm{H}, J=8.0 \mathrm{~Hz}, \mathrm{H}_{\text {arom }}\right), 7.91-7.88$ (m, 2H, Phth), $7.78-7.75\left(\mathrm{~m}, 3 \mathrm{H}, 2 \mathrm{H}_{\text {Phth }}\right.$ and $\left.\mathrm{H}_{\text {arom }}\right), 7.47(\mathrm{t}, 1 \mathrm{H}, J=7.6 \mathrm{~Hz}$, $\left.\mathrm{H}_{\text {arom }}\right), 7.35\left(\mathrm{t}, 1 \mathrm{H}, J=7.6 \mathrm{~Hz}, \mathrm{H}_{\text {arom }}\right), 6.15\left(\mathrm{~s}, 2 \mathrm{H}, \mathrm{NCH}_{2}\right)$, $4.74\left(\mathrm{~s}, 2 \mathrm{H}, \mathrm{SCH}_{2}\right) .{ }^{13} \mathrm{C}-\mathrm{NMR}\left(100 \mathrm{MHz}, \mathrm{CDCl}_{3}\right): \delta=166.3$

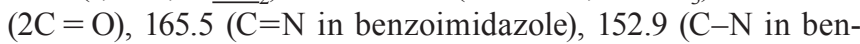
zoimidazole), 144.4 ( $\mathrm{C}$ in triazole), $135.3(\mathrm{NCH}=$ in triazole), 134.7 (2C in phthalimide), 131.2 (2C in phthalimide), 126.0 (C-S), 124.3 (C-Ar), 124.1 (C-Ar), 124.0 (2C in phthalimide), 121.5 (C-Ar), 121.0 (C-Ar), $49.6\left(\mathrm{CH}_{2}\right.$-triazole), $27.5\left(\mathrm{CH}_{2}-\mathrm{S}\right)$. Anal. Calcd $\mathrm{C}_{19} \mathrm{H}_{13} \mathrm{~N}_{5} \mathrm{O}_{2} \mathrm{~S}_{2}$ : C, 56.01; H, 3.22. Found: C, 55.70; H, 3.61.

4-(Benzothiazol-2-ylsulfanyl)-methyl-1-[2-(phthalimido-2yl)ethyl]-1H-1,2,3-triazole (3b)

Brown solid; mp: $140-142^{\circ} \mathrm{C}$; Rf 0.4 (Hexane-EtOAc, $1: 1)$; IR (KBr) $v_{\max } 3140,2959,1781,1721,1460,1430$, 1400, 1313, 1012, 942, 760, $720 \mathrm{~cm}^{-1} ;{ }^{1} \mathrm{H}-\mathrm{NMR}(400 \mathrm{MHz}$, $\left.\mathrm{CDCl}_{3}\right): \delta=7.87\left(\mathrm{~d}, 1 \mathrm{H}, J=8.4 \mathrm{~Hz}, \mathrm{H}_{\text {arom }}\right), 7.75-7.72(\mathrm{~m}, 4 \mathrm{H}$, $2 \mathrm{H}_{\text {Phth }}, \mathrm{H}_{\text {arom }}$ and $\left.\mathrm{H}_{\text {triaz }}\right), 7.66-7.64(\mathrm{~m}, 2 \mathrm{H}, \mathrm{Phth}), 7.42(\mathrm{t}, 1 \mathrm{H}$, $\left.J=7.2 \mathrm{~Hz}, \mathrm{H}_{\text {arom }}\right), 7.31\left(\mathrm{t}, 1 \mathrm{H}, J=7.2 \mathrm{~Hz}, \mathrm{H}_{\text {arom }}\right), 4.67(\mathrm{~s}, 2 \mathrm{H}$, 

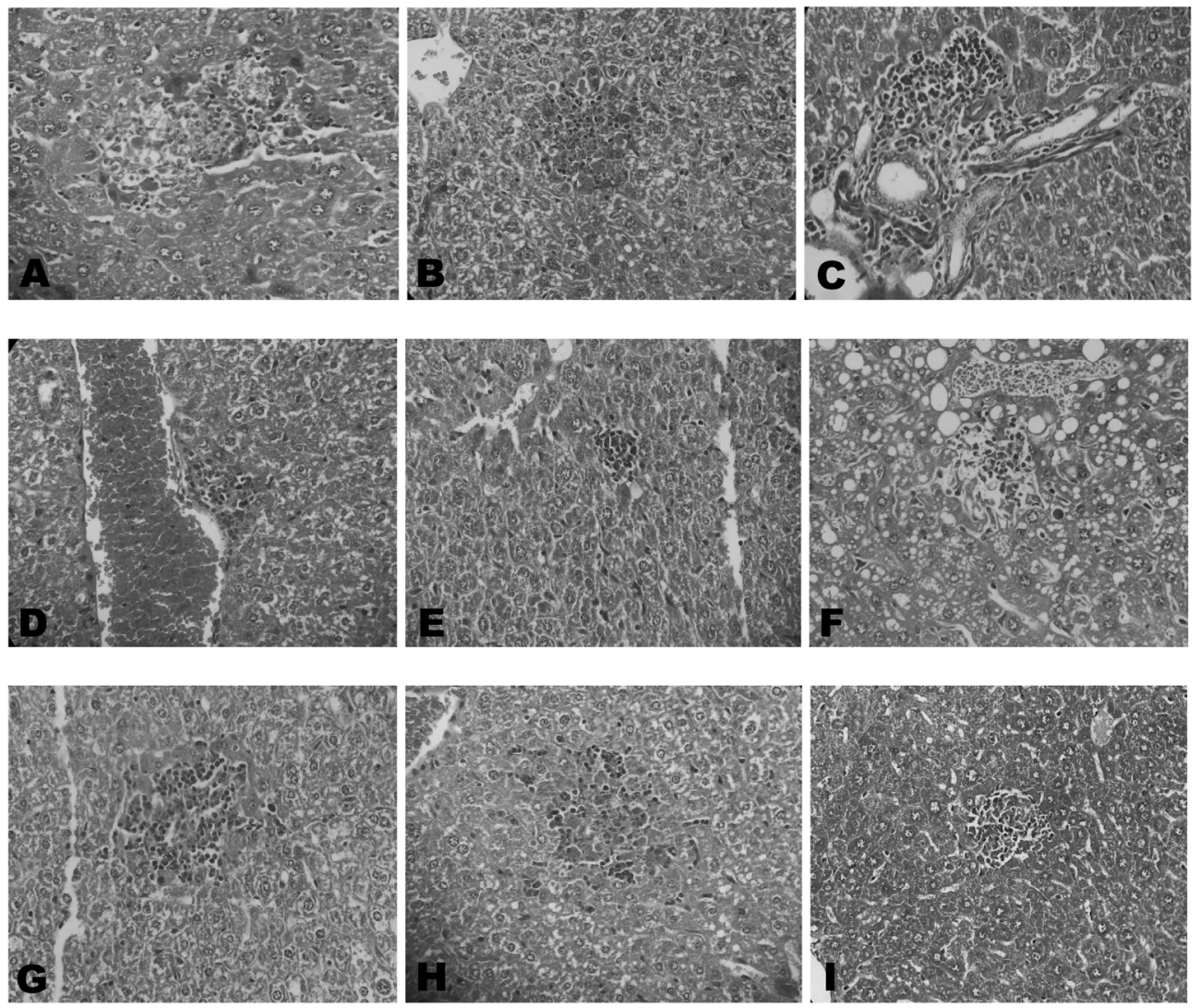

Fig. 5. Hepatic Histopathological Findings in the Mice Tested for Substances 3a-d, 4a-d and Control Negative

Minimum foci of hepatocyte necrosis in animals tested for substances 3a (A), 3b (B), 4a (E), 4b (F), 4c (G), 4d (H) and control group (I). Non-specific, discrete chronic inflammatory infiltrate in mice tested for $\mathbf{3} \mathbf{c}(\mathrm{C})$ and $\mathbf{3 d}(\mathrm{D})$. In $\mathrm{F}$ image, there are also foci of macro and microvesicular steatosis (mouse tested for compound $\mathbf{4 b}$ ). (H\&E $\times 400)$.

$\left.\mathrm{SCH}_{2}\right), 4.64\left(\mathrm{t}, 2 \mathrm{H}, J 5.6 \mathrm{~Hz}, \mathrm{NCH}_{2}\right), 4.12(\mathrm{t}, 2 \mathrm{H}, J 5.6 \mathrm{~Hz}$, $\left.\mathrm{NCH}_{2}\right) .{ }^{13} \mathrm{C}-\mathrm{NMR} \quad\left(100 \mathrm{MHz}, \mathrm{CDCl}_{3}\right): \delta=167.5 \quad(2 \mathrm{C}=\mathrm{O})$, $166.3(\mathrm{C}=\mathrm{N}$ in benzoimidazole $), 152.4(\mathrm{C}-\mathrm{N}$ in benzoimidazole), 144.2 (C in triazole), $135.2(\mathrm{NCH}=$ in triazole), 134.2 (2C in phthalimide), 131.5 (2C in phthalimide), 126.2 (C-S), 124.5 (C-Ar), 123.4 (2C in phthalimide), 123.3 (C-Ar), 121.3 (C-Ar), 121.1 (C-Ar), $48.0\left(\mathrm{CH}_{2}\right.$-triazole), $37.6\left(\mathrm{CH}_{2}\right), 27.7$ $\left(\mathrm{CH}_{2}-\mathrm{S}\right)$. Anal. Calcd $\mathrm{C}_{20} \mathrm{H}_{15} \mathrm{~N}_{5} \mathrm{O}_{2} \mathrm{~S}_{2}: \mathrm{C}, 56.99 ; \mathrm{H}, 3.59$. Found: C, 57.35; H, 3.96.

4-(Benzothiazol-2-ylsulfanyl)-methyl-1-[3-(phthalimido-3yl)propyl]-1H-1,2,3-triazole (3c)

Brown solid; mp: $124-127^{\circ} \mathrm{C}$; $R f 0.5$ (Hexane-EtOAc, $1: 1$ ); ${ }^{1} \mathrm{H}-\mathrm{NMR}\left(400 \mathrm{MHz}, \mathrm{CDCl}_{3}\right): \delta=7.93\left(\mathrm{~d}, 1 \mathrm{H}, \mathrm{H}_{\text {arom }}\right), 7.84-7.82$ (m, 2H, 2 $\left.\mathrm{H}_{\mathrm{Phth}}\right), 7.76-7.72\left(\mathrm{~m}, 4 \mathrm{H}, 2 \mathrm{H}_{\mathrm{Phth}}, \mathrm{H}_{\text {triaz }}\right.$ and $\left.\mathrm{H}_{\text {arom }}\right), 7.41$ (t, $1 \mathrm{H}, J=7.2 \mathrm{~Hz}, \mathrm{H}_{\text {arom }}$ ), 7.29 (t, $\left.1 \mathrm{H}, J=7.6 \mathrm{~Hz}, \mathrm{H}_{\text {arom }}\right), 4.69$ (s, $\left.2 \mathrm{H}, \mathrm{SCH}_{2}\right), 4.36\left(\mathrm{t}, J=6.8 \mathrm{~Hz}, 2 \mathrm{H}, \mathrm{NCH}_{2}\right), 3.70(\mathrm{t}, J=6.4 \mathrm{~Hz}$, $2 \mathrm{H}, \mathrm{NCH}_{2}$ ), 2.30 (qt, $2 \mathrm{H}, J=6.8 \mathrm{~Hz}, \mathrm{CH}_{2}$ ). The IR, ${ }^{1} \mathrm{H}-$ and ${ }^{13} \mathrm{C}-\mathrm{NMR}$ are in accordance with previously reported data. ${ }^{27)}$

4-(Benzothiazol-2-ylsulfanyl)-methyl-1-[4-(phthalimido-4yl)butyl]-1H-1,2,3-triazole (3d)

Brown solid; mp: $109-113^{\circ} \mathrm{C} ; R f 0.4$ (Hexane-EtOAc, $1: 1$ ); ${ }^{1} \mathrm{H}-\mathrm{NMR} \quad\left(400 \mathrm{MHz}, \mathrm{CDCl}_{3}\right): \delta=7.90(\mathrm{~d}, 1 \mathrm{H}, J=8.0 \mathrm{~Hz}$, $\left.\mathrm{H}_{\text {arom }}\right), 7.81-7.78$ (m, 2H, Phth), 7.36 (d, 1H, J=7.6 Hz, $\mathrm{H}_{\text {arom }}$ ), 7.71-7.68 (m, 2H, Phth), $7.64\left(\mathrm{~s}, 1 \mathrm{H}, \mathrm{H}_{\text {triaz }}\right), 7.41(\mathrm{dd}, 1 \mathrm{H}$, $J=7.6$ and $\left.7.6 \mathrm{~Hz}, \mathrm{H}_{\text {arom }}\right), 7.28\left(\mathrm{dd}, 1 \mathrm{H}, J=7.6,7.6 \mathrm{~Hz}, \mathrm{H}_{\text {arom }}\right)$, 4.68 (s, $\left.2 \mathrm{H}, \mathrm{SCH}_{2}\right), 4.34$ (t, $\left.2 \mathrm{H}, J=7.2 \mathrm{~Hz}, \mathrm{NCH}_{2}\right), 3.67$ (t, $2 \mathrm{H}$, $J=6.8 \mathrm{~Hz}, \mathrm{NCH}_{2}$ ), 1.90 (qt, $2 \mathrm{H}, J=7.6 \mathrm{~Hz}, \mathrm{CH}_{2}$ ), 1.67 (qt, $2 \mathrm{H}$, $\left.J=7.2 \mathrm{~Hz}, \mathrm{CH}_{2}\right)$. The IR, ${ }^{1} \mathrm{H}-$ and ${ }^{13} \mathrm{C}-\mathrm{NMR}$ are in accordance with previously reported data. ${ }^{27)}$
4-Phenyl-1-( $N$-phthalimidomethyl)-1 $H$-1,2,3-triazole (4a)

Colorless solid; mp: $200-203^{\circ} \mathrm{C}$; Rf 0.5 (EtOAc-Hexane, $8: 2)$; IR (KBr) $v_{\max } 3130,3046,2940,1780,1721,1543,1401$, 1358, 1211, 1041, 761, $717 \mathrm{~cm}^{-1}$. The ${ }^{1} \mathrm{H}-$ and ${ }^{13} \mathrm{C}-\mathrm{NMR}$ are in accordance with previously reported data. ${ }^{28)}$

4-Phenyl-1-[2-(phthalimido-2-yl)ethyl]-1H-1,2,3-triazole (4b)

Colorless solid; mp: $187-189^{\circ} \mathrm{C}$; Rf 0.4 (EtOAc-Hexane, $1: 1)$; IR (KBr) $v_{\max } 3126,2952,1774,1716,1464,1432,1396$, 1231, 1078, 765, $720 \mathrm{~cm}^{-1}$; ${ }^{1} \mathrm{H}-\mathrm{NMR}\left(400 \mathrm{MHz}, \mathrm{DMSO}-d_{6}\right)$ : $\delta=8.64\left(\mathrm{~s}, 1 \mathrm{H}, \mathrm{H}_{\text {triaz }}\right), 7.87-7.82(\mathrm{~m}, 4 \mathrm{H}, \mathrm{Phth}), 7.77$ (d, 2H, $\left.J=8.0 \mathrm{~Hz}, \mathrm{H}_{\text {arom }}\right), 7.43\left(\mathrm{t}, 2 \mathrm{H}, J=7.6 \mathrm{~Hz}, \mathrm{H}_{\text {arom }}\right), 7.32(\mathrm{t}, 1 \mathrm{H}$, $\left.J=7.6 \mathrm{~Hz}, \mathrm{H}_{\text {arom }}\right), 4.69\left(\mathrm{t}, 2 \mathrm{H}, J=6.0 \mathrm{~Hz}, \mathrm{NCH}_{2}\right), 4.06(\mathrm{t}, 2 \mathrm{H}$, $\left.J=5.6 \mathrm{~Hz}, \mathrm{NCH}_{2}\right)$. The ${ }^{13} \mathrm{C}-\mathrm{NMR}$ is in accordance with previously reported data. ${ }^{29)}$

4-Phenyl-1-[3-(phthalimido-3-yl)propyl]-1H-1,2,3-triazole (4c)

Colorless solid; mp: $144-146^{\circ} \mathrm{C}$; Rf 0.4 (EtOAc-Hexane, $1: 1)$; IR (KBr) $v_{\max } 3090,1767,1713,1399,1338,1027,767$, $717 \mathrm{~cm}^{-1} ;{ }^{1} \mathrm{H}-\mathrm{NMR}\left(400 \mathrm{MHz}, \mathrm{CDCl}_{3}\right): \delta=8.00\left(\mathrm{~s}, 1 \mathrm{H}, \mathrm{H}_{\text {triaz }}\right)$, 7.86-7.81 (m, 3H, $2 \mathrm{H}_{\text {Phth }}$ and $\left.\mathrm{H}_{\text {arom }}\right), 7.75-7.71$ (m, 2H, Phth), $7.42\left(\mathrm{~d}, 2 \mathrm{H}, J=8 \mathrm{~Hz}, \mathrm{H}_{\text {arom }}\right), 7.42\left(\mathrm{t}, 2 \mathrm{H}, J=8 \mathrm{~Hz}, \mathrm{H}_{\text {arom }}\right), 7.33$ $\left(\mathrm{t}, 1 \mathrm{H}, J=8 \mathrm{~Hz}, \mathrm{H}_{\text {arom }}\right), 4.46\left(\mathrm{t}, 2 \mathrm{H}, J=8 \mathrm{~Hz}, \mathrm{NCH}_{2}\right), 3.79(\mathrm{t}$,

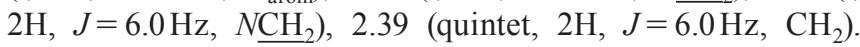
${ }^{13} \mathrm{C}-\mathrm{NMR}\left(100 \mathrm{MHz}, \mathrm{CDCl}_{3}\right): \delta=168.4(2 \mathrm{C}=\mathrm{O}), 147.7(\mathrm{C}$ in triazole), 134.2 (2C in phthalimide), $131.8(\mathrm{NCH}=$ in triazole), 130.5 (C-Ar), 128.8 (2C in phthalimide), 128.1 (2C-Ar), 125.7 (2C in phthalimide), 123.4 (2C-Ar), 120.3 (C-Ar), $47.8\left(\mathrm{CH}_{2}-\right.$ triazole), $35.0\left(\mathrm{CH}_{2}-\mathrm{Phth}\right), 29.4\left(\mathrm{CH}_{2}\right)$. Anal. Calcd $\mathrm{C}_{19} \mathrm{H}_{16} \mathrm{~N}_{4} \mathrm{O}_{2}$ 

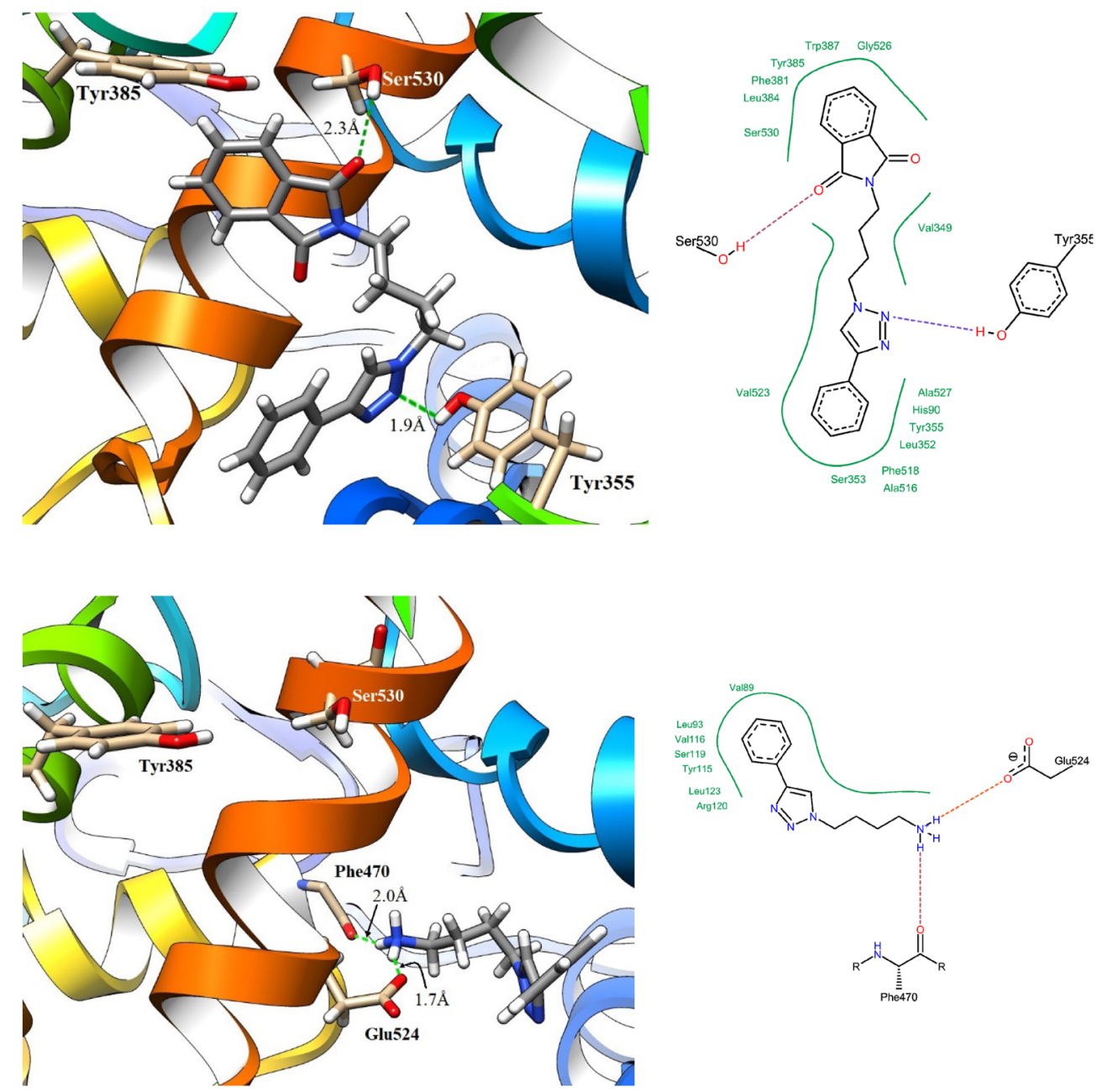

Fig. 6. Molecules $\mathbf{4 d}$ (Upper) and $\mathbf{5}$ (Lower) Docked into the Active Site of COX-2 (Color figure can be accessed in the online version.)

$\left(1 \times \mathrm{H}_{2} \mathrm{O}\right)$ : C, 65.13; H, 5.18. Found: C, 65.07; H, 5.26.

4-Phenyl-1-[4-(phthalimido-4-yl)butyl]-1H-1,2,3-triazole (4d)

Yellow solid; mp: $115-118^{\circ} \mathrm{C}$; Rf 0.5 (EtOAc-Hexane, $1: 1$ ); IR $(\mathrm{KBr}) v_{\max } 3126,2952,1766,1708,1399,1364,1082,764$, $721 \mathrm{~cm}^{-1} ;{ }^{1} \mathrm{H}-\mathrm{NMR}\left(400 \mathrm{MHz}, \mathrm{CDCl}_{3}\right): \delta=7.84-7.82(\mathrm{~m}, 5 \mathrm{H}$, $2 \mathrm{H}_{\text {Phth }}, 2 \mathrm{H}_{\text {arom }}$ and $\mathrm{H}_{\text {triaz }}$ ), $7.72-7.69$ (m, 2H, Phth), $7.41(\mathrm{t}, 2 \mathrm{H}$, $\left.J=6.8 \mathrm{~Hz}, \mathrm{H}_{\text {arom }}\right), 7.32\left(\mathrm{t}, 1 \mathrm{H}, J=7.2 \mathrm{~Hz}, \mathrm{H}_{\text {arom }}\right), 4.47(\mathrm{t}, 2 \mathrm{H}$, $J=6.8 \mathrm{~Hz}, \mathrm{NCH}_{2}$ ), 3.75 (t, $2 \mathrm{H}, J=6.8 \mathrm{~Hz}, N_{2} \mathrm{H}_{2}$ ), 2.00 (qt, $\left.2 \mathrm{H}, J=7.6 \mathrm{~Hz}, \mathrm{CH}_{2}\right), 1.76\left(\mathrm{qt}, 2 \mathrm{H}, J=7.2 \mathrm{~Hz}, \mathrm{CH}_{2}\right) .{ }^{13} \mathrm{C}-\mathrm{NMR}$ $\left(100 \mathrm{MHz}, \mathrm{CDCl}_{3}\right): \delta=167.9(2 \mathrm{C}=\mathrm{O}), 146.2(\mathrm{C}$ in triazole), 134.3 (2C in phthalimide), $131.6(\mathrm{NCH}=$ in triazole), 130.8 (C-Ar), 128.8 (2C in phthalimide), 127.7 (2C-Ar), 125.0 (2C in phthalimide), 122.9 (2C-Ar), 121.2 (C-Ar), $48.9\left(\mathrm{CH}_{2}-\right.$ triazole), $36.7\left(\mathrm{CH}_{2}-\mathrm{Phth}\right), 27.2\left(\mathrm{CH}_{2}\right), 25.0\left(\mathrm{CH}_{2}\right)$. Anal. Calcd $\mathrm{C}_{20} \mathrm{H}_{18} \mathrm{~N}_{4} \mathrm{O}_{2}\left(1 / 2 \mathrm{H}_{2} \mathrm{O}\right): \mathrm{C}, 67.59 ; \mathrm{H}, 5.39$. Found: $\mathrm{C}, 67.37 ; \mathrm{H}$, 5.57 .

Synthesis of 4-(4-Phenyl-1H-1,2,3-triazol-1-yl)butan1-amine (5) The compound 5 was prepared from $4 \mathbf{d}$ according to the procedure described in the literature. ${ }^{32)}$ The ${ }^{1} \mathrm{H}$ - and ${ }^{13} \mathrm{C}-\mathrm{NMR}$ are in accordance with previously reported data. ${ }^{32}$

Synthesis of $\mathrm{N}$-[4-(4-Phenyl-1H-1,2,3-triazol-1-yl)butyl]acetamide (6) $300 \mathrm{mg}(1.38 \mathrm{mmol})$ of 4-(4-phenyl- $1 \mathrm{H}-1,2,3$ triazol-1-yl)butan-1-amine $\mathbf{5}, 1.5 \mathrm{~mL}$ of acetic anhydride, $3.0 \mathrm{~mL}$ of pyridine and catalytic amount of DMAP were mixed. After $12 \mathrm{~h}$ of reaction, the mixture was co-evaporated with toluene. The residue was purified by column chromatography. Yield $=61 \%$ (ratio rotamers $=69: 31$ ); yellow solid; $\mathrm{mp}$ 167-170 ${ }^{\circ} \mathrm{C}$; Rf 0.6 (MeOH-EtOAc, $\left.1: 9\right) .{ }^{1} \mathrm{H}-\mathrm{NMR}(300 \mathrm{MHz}$, $\left.\mathrm{CDCl}_{3}\right): \delta=7.88\left(\right.$ brs, $\left.1 \mathrm{H}, \mathrm{H}_{\text {triaz }}\right), 7.83-7.78\left(\mathrm{~m}, 2 \mathrm{H}, \mathrm{H}_{\text {arom }}\right)$, $7.43\left(\mathrm{dd}, 2 \mathrm{H}, J=7.7\right.$ and $\left.7.0 \mathrm{~Hz}, \mathrm{H}_{\text {arom }}\right), 7.34(\mathrm{t}, 1 \mathrm{H}, J=7.0$ and $7.0 \mathrm{~Hz}, \mathrm{H}_{\text {arom }}$ ), 6.07 (brs, $1 \mathrm{H}, N \underline{H A c}$ ), 4.47 (t, $2 \mathrm{H}, J=6.4 \mathrm{~Hz}$, $\mathrm{CH}_{2}$-triazole), 3.30 (app quartet, $2 \mathrm{H}, \mathrm{J}=6.4 \mathrm{~Hz}, \mathrm{NCH}_{2}$ ), 2.15 (quintet, $2 \mathrm{H}, J=6.4 \mathrm{~Hz}, \mathrm{CH}_{2}$ ), 1.96 (brs, $3 \mathrm{H}, \mathrm{CH}_{3}$ ), 1.87 (brs, $2 \mathrm{H}, \mathrm{CH}_{2}$ ). Rotamer (visible signals): $\delta=6.39$ (brs, $1 \mathrm{H}$, NHAc), 4.54 (t, 2H, $J=5.3 \mathrm{~Hz}, \mathrm{CH}_{2}$-triazole), 3.81 (app quartet, $2 \mathrm{H}, J=5.9 \mathrm{~Hz}, \mathrm{NCH}_{2}$ ), 1.99 (brs, $\left.3 \mathrm{H}, \mathrm{CH}_{3}\right) .{ }^{13} \mathrm{C}-\mathrm{NMR}$ $\left(75.4 \mathrm{MHz}, \mathrm{CDCl}_{3}\right): \delta=170.7(\mathrm{C}=\mathrm{O}), 147.9$ (C in triazole), $130.4(\mathrm{NCH}=$ in triazole), 128.9 (2C-Ar), 128.2 (C-Ar), 125.6 (2C-Ar), 120.1 (C-Ar), 47.9, 36.5, 30.1, $23.2\left(4 \mathrm{CH}_{2}\right)$. Rotamer (visible signals): $\delta=170.8,130.2,128.3,120.5,49.6,39.4,23.1$. Anal. Calcd $\mathrm{C}_{14} \mathrm{H}_{18} \mathrm{~N}_{4} \mathrm{O}$ : C, 65.09; H, 7.02. Found: C, 65.01; H, 7.31 .

\section{Pharmacology}

Drugs

ASA, ibuprofen (Laboratory Teuto Brazilian Ltda., Brazil), CMC and Carrageenan (Sigma, St. Louis, U.S.A.) were used in the biological assay.

Animals

Three month-old Swiss white mice, $25-30 \mathrm{~g}$ body weight, 
were maintained with water and food (Labina-Agribands Brazil Ltd.) ad libitum. Groups of 6 animals were separated for each experiment. All the experimental procedures reported here were performed in accordance with the Animal Care and Use Committee of the Federal University of Pernambuco and guidelines for Care and Use of Laboratory Animals (Of. $\mathrm{n}^{\circ}$ 098/2002).

\section{Toxicity against Artemia salina}

The toxicity test on brine shrimp has been established as a safe, practical, and economic method for the synthetic compounds bioactivity determination. ${ }^{33)}$ The brine shrimp lethality bioassay was performed following the reported procedure. Initially, the brine was collected from sea water (approximately 2L) from an uncontaminated site, Tamandaré Beach in the state of Pernambuco, Brazil. The growth medium was prepared with a simple filtration of the water collected and sodium carbonate was used to adjust the $\mathrm{pH}$ to between 8 and 9. After 24h, the Artemia salina were counted (using a Pasteur pipette and watch glass) and placed in tapered tubes. In each tube were placed ten Artemia salina. In addition to this, a stock solution was prepared for each compound tested 3a-d and 4a-d. The stock solutions were prepared with $50 \mathrm{mg}$ of each compound, in $5 \mathrm{~mL}$ of $1 \% \mathrm{CMC}(\mathrm{w} / \mathrm{v})$. The stock had their concentrations measured in parts per million (ppm); each stock solution was used for testing with the following concentrations: $100 \mathrm{ppm}(50 \mu \mathrm{L}), 250 \mathrm{ppm}(125 \mu \mathrm{L}), 500 \mathrm{ppm}$ $(250 \mu \mathrm{L}), 750 \mathrm{ppm}(375 \mu \mathrm{L})$ and $1000 \mathrm{ppm}(500 \mu \mathrm{L})$. After each aliquot was pipetted, the volume was topped up with $5 \mathrm{~mL}$ of sea water. The control group was made up of only $2 \mathrm{~mL}$ of $1 \%$ carboxymethylcellulose and the volume topped up with sea water to a total volume of $5 \mathrm{~mL}$. The reading was taken after $24 \mathrm{~h}$ with the numbers of dead and live larvae being recorded.

Acute Toxicity in Vivo

Graded doses $\left(50-1000 \mathrm{mg} \mathrm{kg}^{-1}\right)$ were administered orally to groups of 6 mice. $^{34)}$ On the first day, the animals were observed every $10 \mathrm{~min}$ for $4 \mathrm{~h}$ followed by twice a day observation at 24, 48 and $72 \mathrm{~h}$ after administration. Changes in spontaneous motor activity, reflex, gait, and respiration, appearance of writhing and piloerection plus mortality were recorded.

\section{In Vivo Anti-inflammatory Activity}

The drugs used for comparison purposes were $\mathbf{3 a}-\mathbf{d}, \mathbf{4 a}-\mathbf{d}$, ASA and ibuprofen. All compounds were suspended in $1 \%$ CMC and single dose of $250 \mathrm{mg} \mathrm{kg}^{-1}$ was administered orally, in the morning. Another animal group received $1 \% \mathrm{CMC}$. One positive and negative anti-inflammatory control tests were carried out with three animal groups by oral administration of $250 \mathrm{mg} \mathrm{kg}^{-1}$ of ASA, a standard dose for pharmacological comparative tests and $0.9 \%$ of aqueous saline solution, respectively. The anti-inflammatory activity was determined by Levy's method. ${ }^{35)}$ Carrageenan, $0.1 \mathrm{~mL}$ of a $1 \%$ solution in $0.9 \% \mathrm{NaCl}$, was injected through the plantar tissue of the right hind paw of each mouse to produce inflammation. The test groups received the synthesized compounds orally in the same dosage as the standard drug, $1 \mathrm{~h}$ before the administration of carrageenan. The paw edema was measured using a digital vernier caliper at intervals of $1,2,3,4,24$, and $48 \mathrm{~h}$. The results were analyzed according to the percentage of inflammation reduction as described earlier. ${ }^{36)}$

Histopathological Analysis

The liver and kidney slices were fixed instantaneously in neutral formalin $(10 \%)$ buffer for $48 \mathrm{~h}$ then processed in automatic processors, embedded in paraffin wax to obtain paraffin blocks. Sections of $5 \mu \mathrm{m}$ thicknesses were prepared and stained with haematoxylin and eosin (H\&E). The slices were examined and photographed under a light microscope (Olympus $^{\circledR}$ CX 41 and 21 microscopes) at a magnification power of $\times 40, \times 100$ and $\times 400$. $^{37)}$ Images of the microscopic findings were obtained through a digital camera (Samsung $^{\circledR}$ smartphone).

Statistical Analysis Results are expressed as the mean \pm standard error of the mean (S.E.M.), and different groups were compared using one way ANOVA followed by Bonfferone posttests for multiple comparisons.

Molecular Docking The structure of the Human COX-2 co-crystallized with meclofenamic acid at $2.41 \AA$ resolution was obtained from the Protein Data Bank (PDBID:5ikq). ${ }^{38)}$ The dockings were performed with the FlexX algorithm ${ }^{39}$ ) implemented into BioSolveIT LeadIT v.2.3.2.40) The ligand was protonated as in aqueous solution, and we allowed 400 maximum solutions per interaction and fragmentation. Only chain A was considered, and the binding site was defined to include all residues with atoms within $12 \AA$ of any atom of the crystallographic ligand.

Acknowledgments The authors are grateful to National Council for Scientific and Technological Development-CNPq (Grant 448082/2014-4), Fundação de Amparo à Ciência e Tecnologia do Estado de Pernambuco-FACEPE (Grant Nos. APQ-0459-1.06/15 and APQ-0741.106/14) and National Council for the Improvement of Higher Education-CAPES for financial support. We also thanks to BioSolveIT for waiving the licensing fee for LeadIT software. We are indebted to Analytical Centers DQF-UFPE and CENAPESQ-UFRPE."

Conflict of Interest The authors declare no conflict of interest.

\begin{tabular}{|c|c|}
\hline Ret & \\
\hline 1) & Sharma U., Kumar P., Kumar N., Singh B., Mini Rev. Med. Chem., \\
\hline & 10, 678-704 (2010). \\
\hline 2) & Kok S. H. L., Gambari R., Chui C. H., Yuen M. C. W., Lin E., \\
\hline & Wong R. S. M., Lau F. Y., Cheng G. Y. M., Lam W. S., Chan S. H., \\
\hline & Lam K. H., Cheng C. H., Lai P. B. S., Yu M. W. Y., Cheung F., Tang \\
\hline & J. C. O., Chan A. S. C., Bioorg. Med. Chem., 16, 3626-3631 (2008). \\
\hline 3) & Horne W. S., Yadav M. K., Stout C. D., Ghadiri M. R., J. Am. \\
\hline & Chem. Soc., 126, 15366-15367 (2004). \\
\hline 4) & Dalvie D. K., Kalgutkar A. S., Khojasteh-Bakht S. C., Obach R. S., \\
\hline & O’Donnell J. P., Chem. Res. Toxicol., 15, 269-299 (2002). \\
\hline 5) & Dheer D., Singh V., Shankar R., Bioorg. Chem., 71, 30-54 (2017). \\
\hline 6) & Bonandi E., Christodoulou M. S., Fumagalli G., Perdicchia D., Ras- \\
\hline & telli G., Passarella D., Drug Discov. Today, 22, 1572-1581 (2017). \\
\hline 7) & Schulze B., Schubert U. S., Chem. Soc. Rev., 43, 2522-2571 (2014). \\
\hline & Silva G. B., Guimarães B. M., Assis S. P. O., Lima V. L. M., de \\
\hline & Oliveira R. N., J. Braz. Chem. Soc., 24, 914-921 (2013). \\
\hline 9) & De Oliveira R. N., Xavier A. D. L., Guimarães B. M., eMelo V. N., \\
\hline & Valença W. O., Do Nascimento W. S., Da Costa P. L. F., Camara C. \\
\hline & A., J. Chil. Chem. Soc., 59, 2610-2614 (2014). \\
\hline 10) & Rostovtsev V. V., Green L. G., Fokin V. V., Sharpless K. B., Angew. \\
\hline & Chem. Int. Ed., 41, 2596-2599 (2002). \\
\hline 11) & Tornøe C. W., Christensen C., Meldal M., J. Org. Chem., 67, 3057- \\
\hline & 3064 (2002). \\
\hline & Meldal M., Tornøe C. W., Chem. Rev., 108, 2952-3015 (2008). \\
\hline & Toguchi S., Hirose T., Yorita K., Fukui K., Sharpless K. B., Ōmu \\
\hline
\end{tabular}


S., Sunazuka T., Chem. Pharm. Bull., 64, 695-703 (2016).

14) Kolb H. C., Sharpless K. B., Drug Discov. Today, 8, 1128-1137 (2003).

15) Thirumurugan P., Matosiuk D., Jozwiak K., Chem. Rev., 113, $4905-$ 4979 (2013)

16) Shafi S., Alam M. M., Mulakayala N., Mulakayala C., Vanaja G., Kalle A. M., Pallu R., Alam M. S., Eur. J. Med. Chem., 49, 324-333 (2012).

17) Goyard D., Docsa T., Gergely P., Praly J.-P., Vidal S., Carbohydr. Res., 402, 245-251 (2015).

18) Goyard D., Baron M., Skourti P. V., Chajistamatiou A. S., Docsa T., Gergely P., Chrysina E. D., Praly J.-P., Vidal S., Carbohydr. Res., 364, 28-40 (2012).

19) Gonçalves J. C. R., Coulidiati T. H., Monteiro A. L., de CarvalhoGonçalves L. C. T., de Oliveira Valença W., de Oliveira R. N., de Câmara C. A., de Araújo D. A. M., J. Appl. Biomed., 14, 229-234 (2016).

20) Assis S. P. O., da Silva M. T., de Oliveira R. N., Lima V. L. M., Sci. World J., 2012, 925925 (2012).

21) Assis S. P. O., Araújo T. G., Sena V. L. M., Catanho M. T. J. A., Ramos M. N., Srivastava R. M., Lima V. L. M., Med. Chem. Res., 23, 708-716 (2014).

22) Lima L. M., Castro P., Machado A. L., Fraga C. A. M., Lugnier C., de Moraes V. L. G., Barreiro E. J., Bioorg. Med. Chem., 10, 3067-3073 (2002).

23) Filho R. A. W. N., Palm-Forster M. A. T., de Oliveira R. N., Synth. Commun., 43, 1571-1576 (2013).

24) Silva M. T., Oliveira R. N., Valença W. O., Barbosa F. C. G., Silva M. G., Camara C. A., J. Braz. Chem. Soc., 23, 1839-1843 (2012).

25) Sena V. L. M., Srivastava R. M., Oliveira S. P., Lima V. L. M., Bioorg. Med. Chem. Lett., 11, 2671-2674 (2001).

26) Sena V. L. M., Srivastava R. M., Silva R. O., Lima V. L. M., Il
Farmaco, 58, 1283-1288 (2003).

27) Barbosa F. C. G., Oliveira R. N., J. Braz. Chem. Soc., 22, 592-597 (2011).

28) Pérez J. M., Cano R., Ramón D. J., RSC Adv., 4, 23943-23951 (2014).

29) Sirion U., Lee J. H., Bae Y. J., Kim H. J., Lee B. S., Chi D. Y., Bull. Korean Chem. Soc., 31, 1843-1847 (2010).

30) Alanazi A. M., El-Azab A. S., Al-Suwaidan I. A., ElTahir K. E. H., Asiri Y. A., Abdel-Aziz N. I., Abdel-Aziz A. A.-M., Eur. J. Med. Chem., 92, 115-123 (2015).

31) Bach D. H., Liu J. Y., Kim W. K., Hong J. Y., Park S. H., Kim D., Qin S. N., Luu T. T. T., Park H. J., Xu Y. N., Lee S. K., Bioorg. Med. Chem., 25, 3396-3405 (2017).

32) de Oliveira R. N., da Silva M. G., da Silva M. T., Melo V. N., Valença W. O., da Paz J. A., Camara C. A., J. Braz. Chem. Soc., 28, 681-688 (2017)

33) Meyer B. N., Ferrigni N., Putnam J., Jacobsen L., Nichols D., McLaughlin J., Med. Plant Res., 45, 31-34 (1982).

34) US Environmental Protection Agency, Code Federal Regulations. In: Protection of environment. Health effects test guidelines, Washington: US Government Printing Office, pp. 433-465, 1992.

35) Levy L., Life Sci., 8, 601-606 (1969).

36) Winter C. A., Risley E. A., Nuss G. W., Proc. Soc. Exp. Biol. Med., 111, 544-547 (1962).

37) Basyouni W. M., Abbas S. Y., El Shehry M. F., El-Bayouki K. A. M., Aly H. F., Arafa A., Soliman M. S., Arch. Pharm. Chem. Life Sci., 350, 1700183 (2017)

38) Orlando B. J., Malkowski M. G., J. Biol. Chem., 291, 15069-15081 (2016).

39) Kramer B., Rarey M., Lengauer T., Proteins, 37, 228-241 (1999).

40) Biosolve I. T., GmbH, LeadIT Version 2.3.2 www.biosolveit.de/LeadIT, Sankt Augustin, Germany, 2017. 